\title{
COLLABORATION IN DEVELOPING ISLAMIC MICRO FINANCE INSTITUTIONS (IMFS) BASED ON FINANCIAL TECHNOLOGY
}

\author{
Elida Elfi Barus
}

Elida.elfi@gmail.com

\begin{abstract}
In the era of industry 4.0 and the current pandemic, existence of Islamic microfinance institutions, especially sharia cooperatives, have fallen with many obstacles. Therefore, various capital innovations with Company to Company (C2C) collaboration are needed. This collaboration needs to be supported by an accommodating system, so that its development can provide benefits to users, one of which is influenced by the use of Ammana.id's. this is an Islamic fintech which is also assisted by other actors such as regulators, conceptors, owners, mentors and the community (pentahelix) by analyzing the development strategy of Islamic cooperatives with fintech collaboration with the pentahelix approach by interpretative structural modeling (ISM). This paper found that the elements of actors that are Department of Cooperatives and Small-Medium Enterprises are the key elements so that it needs to focus on developing sharia regulations which are then assisted by academics as conceptors in the development of islamic micro finance institutions
\end{abstract}

Keyword : Collaboration, Sharia Financial Technology, pentahelix 


\section{Introduction}

Sharia cooperatives are a non-governmental group as a people's economic institution that seeks to develop productive businesses and investments based on sharia principles and maqasid sharia Zainil Ghulam (2016).Covid-19 has hit hard cooperatives and Micro Finance Institution. The policy of physical distancing or large-scale social restrictions inevitably greatly affects the economic activities of cooperatives and Micro Finance Institution (MFI).

The existence of a significant number of Islamic cooperatives in several regions in Indonesia is not supported by supporting factors that enable these micro-institutions to continue to develop and run well. For the development of sharia cooperatives in the post pandemic, it is necessary to have the facts in the field showing that there are many sharia cooperatives that are sunken and dispersed. Recording for consumer cooperatives are the cooperative segments of daily necessity units which were most severely affected or around 45 percent of the total 781 units, cooperative services as many as 158 units (8 percent), and cooperative producers affected 152 units ( 7 percent). The problem faced is the lack of capital, decreased sales, and distribution is hampered. From the number of cooperatives that existed from 2016 amounted to 151,170 until 2019 to 123,048 cooperatives, only a few percent were active and the active development also declined as illustrated in the figure below.

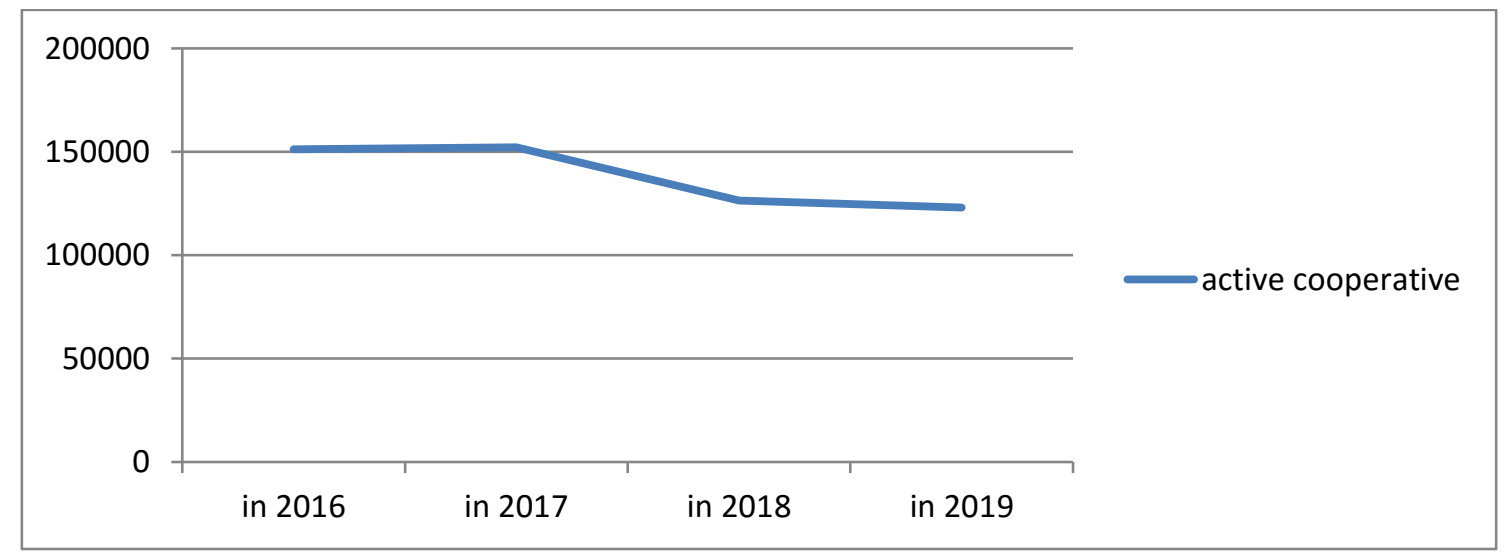

Source: Cooperative Data Report dekop.go.id 2020

Figure 1. Development of Cooperatives in Indonesia

By looking at the phenomena above, the development of cooperatives and sharia cooperatives in Indonesia is seen as not yet fully able to answer the real economic problems that exist in society, especially when the covid pandemic is very foothold in the global economy, including the development of sharia cooperatives or 


\section{Elida Elfi Barus}

Collaboration In Developing Islamic Micro Finance Institutions (IMFs) Based On Financial Technology

KSPPS and Micro Finance Institution. Seen in conception, Islamic cooperatives are institution whose existence is highly needed by the community, especially the micro circles. On the other hand, in the operational field it still has many weaknesses. Then these problems must be overcome properly in order to be able to realize the creation of a positive image for sharia microfinance institutions that are clean and trusted by the public. During this pandemic, the Office of Cooperatives and SMEs continues to provide relief and relaxation for cooperative partners (Micro Finance Institution) in the LPDB-KUMKM (Cooperative Revolving Fund Management Institute and Micro Finance Institution) in order to survive in the midst of the Covid 19 outbreak in the form of a policy of relaxation and financing flexibility in the form of financing restructuring for LPDB-KUMKM recipients. In addition to the financing policy of the government through LPDB, and to simplify it also the era of digitalization is increasingly developing in reducing "physical distancing" is the online model, and now that is floating is Financial Technology (Fintech) although the initial emergence is a threat to financial institutions (banks and even cooperatives) Sirajulhaq and Marifatulhaq (2019), but the need for collaboration in financing developed. Fintech Ammana.id is the only sharia fintech that collaborates with Islamic financial institutions (Koperasi Syariah and KSPPS / BMT) in Indonesia.

Meanwhile, fintech in Indonesia began to develop from 2006 with initially only four companies and grew to 16 in 2007. Significant developments occurred in 2015 to 2016 in which the number of companies running the fintech business model were around 165 companies and 31 of them is sharia fintech which is starting to develop (Lawrance and Basit, 2017) as illustrated below:

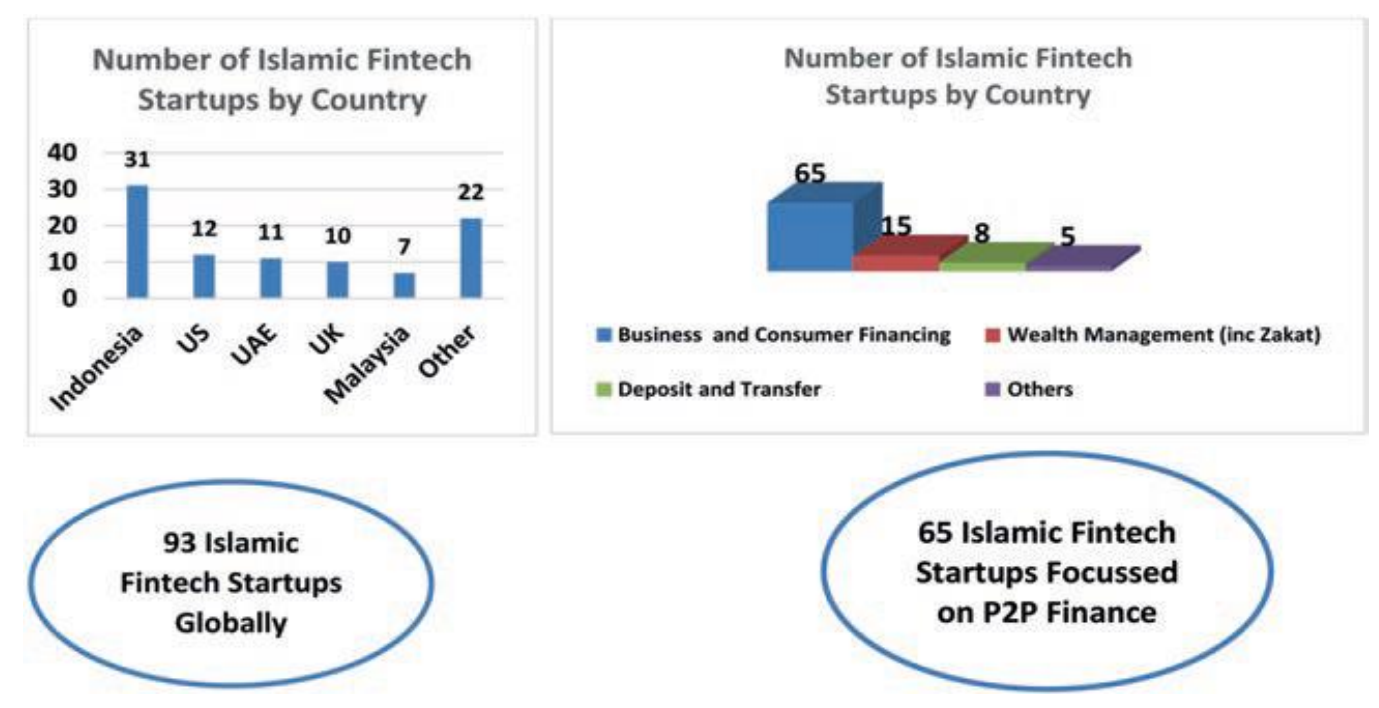

Figure 2. Development of Fintech Indonesia 
Based on the development of fintech above, Indonesia under the FSA as a regulator of the financial industry has issued a legal standing for the fintech industry. The legal umbrella is in the form of OJK Regulation Number 77 / POJK.01 / 2016 concerning Peer-to-Peer Lending / P2P Lending Ownership Loan Services issued at the end of December 2016 and Bank Indonesia No: 19/12 / PBI / 2017 concerning the implementation of Technology financial but these regulations only set fintech with conventional systems and have not set the current islamic system also began to grow.

A number of studies also show a variety of positive impacts on the use of cooperative cooperation in collaborating and synergizing Yuliana Yuliana (2019) with Islamic fintech as Elida and Budi's research (2019), Rusydiana research (2018), Budianto and Julius research (2019) and through sharia cooperative fintech can meet the needs of its customers according to Julianto (2016) and cooperatives can foster fintech-based entrepreneurship Micro Finance Institution as Kusumaningsih (2018) researches to stabilize the financial system according to Yoshida (2019).

However, despite the large number of start-up fintechs, many have grown from 31 fintech companies, only a few, even one sharia fintech cooperating with Islamic cooperatives, namely Ammana.id, and most of fintech directly to the public, B2C, which is still a bit B2B and there are still many studies above. And regulations are only still not perfect until Islamic compliance has not been formulated. According to Alam, Gupta and Zameni (2019) there is still little research on the development strategy of Islamic financial institutions with Islamic fintech.

Therefore, based on the background and gaps that have been disclosed above, this paper intends to examine what are the obstacles faced by Islamic cooperatives in Indonesia, and what are the measures of the effectiveness of the development of sharia cooperative collaboration with Islamic fintech in Indonesia. With the Interpretative Structural Modeling (ISM) approach, some of these questions will be tried to be answered and the solution sought and become a reference for stakeholders for better development in the future.

\section{Literatur Review}

\section{Islamic Cooperative}

In terms of language, generally cooperative comes from Latin words, namely, cum which means with, and apareri which means work. Of these two words in English it is known as co and operation, which in Dutch is called cooperation veregening which means working 


\section{Elida Elfi Barus}

Collaboration In Developing Islamic Micro Finance Institutions (IMFs) Based On Financial Technology

together with other people to achieve a certain goal. Whereas in terms of terminology, a cooperative is an association or organization whose members are people or legal entities that cooperate with full awareness to improve the welfare of members on a voluntary basis in a family manner. Cooperative in Islamic jurisprudence is known as Syirkah Ta'awuniyyah or shrub with the word al-Ikhtilat, which is an association / partnership in an economy that is oriented towards togetherness. In terms of terms, a cooperative is a contract between people to unite for capital and profit.

The term cooperation based on the principle of kinship is also authentically used in the 1945 constitution as a typology of the national economic system. In his explanation, the term joint venture based on the principle of kinship is called a cooperative. In Law 25 of 1992 it is stated that what is meant by cooperatives is a business entity whose members are individuals or a cooperative legal entity based on its activities based on the principles of cooperatives as well as a people's economic movement based on the principle of "kekeluargaan"

\section{Islamic Fintech}

According to the National Digital Research Center (NDRC), financial technology is a term used to describe an innovation in the field of financial services, where the term comes from the words "financial" and "technology" (FinTech) which refers to financial innovation with a touch of modern technology.

Meanwhile, islamic fintech is a financial system whose implementation is based on Islamic law (sharia). The formation of this system is based on the prohibition in Islam to lend or collect loans by charging interest on loans (usury), as well as the prohibition to invest in prohibited businesses (haram), which cannot be guaranteed by conventional systems, or financial services and solutions given by technology companies / fintech startups based on Islamic / sharia laws.

\section{Research Methods}

Interpretive structural modeling is an onward design methodology utilized to recognize, examine and summarize several correlations among factors which explain a problem, issue, or model (Sage, 1977). ISM gives a means where both academicians and researchers can enforce orders and generate models about the factors of a system by expanding the intricacy of the correlation among them (Warfield, 1974). Interpretative Structural Modeling is a decision-making method that stores from the complexity of the situation by correlating and organizing the ideas into the visual map. ISM basic concept is using experts and practitioners to generate complexity of the system into some subsystems (elements) and build a structural 
hierarchy modeling. ISM is also used to give the basic understanding from the complicated situation and arrange the strategy to solve the problem. There is some step to analyze the ISM method; the first stage is problem decomposition to the expert or practitioners (who has better understanding related to the problem discussed / brainstorming) to identify the ideas of the development organization, has a better understanding of financial technology development problems. From this discussion, will be explored the development strategies, and the variables used in the ISM model.

The second stage is the constructing Structural Self Interaction Matrix (SSIM) model. SSIM is constructed from the variables founded from the decomposition step, then develops the contextual relationship between variables and gathering into one variable $i$ and variable $j$. The third stage is creating a reachability matrix (RM) by conversing the $\mathrm{V}, \mathrm{A}, \mathrm{X}$, and $\mathrm{O}$ used into the numbers 1 and 0 .

The rules for this substitution are as follows: (a) If the (i, j) entry in the SSIM is V, then the $(i, j)$ entry in the reachability matrix becomes 1 and the $(j, i)$ entry becomes 0 (b) If the (i, j) entry in the SSIM is $A$, then the (i, j) entry in the matrix becomes 0 and the $(j, i)$ entry becomes 1. (c) If the $(i, j)$ entry in the SSIM is $X$, then the $(i, j)$ entry in the matrix becomes 1 and the $(j, i)$ entry also becomes 1 . (d) If the (i, j) entry in the SSIM is $O$, then the $(i, j)$ entry in the matrix becomes 0 and the $(j, i)$ entry also becomes 0 . The fourth stage is creating a canonical matrix to identify the level through the iteration. If the intersection is not found anymore, the next step is creating the resulting model from the ISM software. The resu lted model is used to solve the problem. From the model also explored the roadmap of effective organizational development (level).

According to Marimin (2004), the process of ISM method is calculated according to the Transivity Rule where the correction of SSIM is done until a closed matrix occurs. SSIM modifications require input from panelists / experts, with special notes for attention shown only on specific sub-elements. The revised results of the SSIM and the matrix are eligible for the Transivity Rules are further processed. For revision can also be done transformation matrix with a computer program.

The last stage is to group sub-elements into 4 sectors (Saxena, 1994):

a. Weak driver _ weak Dependent variables (AUTONOMOUS), variables in this sector are generally not system related, the relationship is small.

b. Weak driver strongly-dependent variables (DEPENDENT), variables included in this group are independent variables, 


\section{Elida Elfi Barus}

Collaboration In Developing Islamic Micro Finance Institutions (IMFs) Based On Financial Technology

c. Strong driver strongly dependent variables (LINKAGE), variables in this sector must be studied carefully because their interactions can have an impact and feedback on the system

d. S trong driver weak Dependent variables (INDEPENDENT) variables in this sector have a strong influence on the system and largely determine the success of the program

There are several studies on Islamic economics and finance that have been done using the ISM method. Some of them are done by Rusydiana and Devi (2018) about sharia cooperatives, Ascarya et al. (2012) about the development of Islamic banks, and Devi and Rusydiana (2016) on the group lending model. Meanwhile Bolanos et al. (2005), and Kanungo \& Batnagar (2002) for other industrial applications. The research using the ISM method with more theoretical has been done by Lee (2007) and Thakkar et al. (2006).

\section{Results and Discussion}

Based on the results of discussions with experts, relevant parties and research in the field obtained various factors that have the potential to produce wastewater whose quality meets environmental quality standards. The factors include, human factors, machinery, materials, equipment and the environment. Of the five factors, further developed and obtained information about sub factors such as, lack of manpower, lack of knowledge about waste treatment, never received technical training, aerators were not able to work optimally, the absence of sludge pumps in sedimentation tanks 1 and 2, no There are Flowmeter devices, no maintenance schedule, limited WWTP area, high production waste volume, no internal testing, wastewater has different characteristics, no daily monitoring of effluent checking like:

E1. Akademic

E2. Financial Fervices Authority dan Bank Central

E3. Sharia Cooperative institutions (KSPPS/BMT)

E4. Fintech Sharia( Ammana.id)

E5. Micro small and Medium Enterprises

E6. Indonesian Sharia Fintech Association (AFSI)

E7. Indonesian Funding Fintech Association (AFPI)

E8. Department of Cooperatives for Micro small and Medium Enterprises

Based on the results of the questionnaire that was filled in by the respondents then made the Structural Self Interaction Matrix (SSIM) matrix as table 1. Furthermore, based on table 1 
about the SSIM matrix then made in the form of the Rechability Matrix (RM) table by replacing $\mathrm{V}, \mathrm{A}, \mathrm{X}, \mathrm{O}$ becomes the numbers 1 and 0 . Thus, the results obtained as table 1 ; .

Table 1. Matrix Structural Self Interaction Matrix (SSIM)

\begin{tabular}{|l|l|l|l|l|l|l|l|l|}
\hline No. & E1 & E2 & E3 & E4 & E5 & E6 & E7 & E8 \\
\hline E1 & & O & V & O & O & O & V & A \\
\hline E2 & & & O & V & V & V & V & A \\
\hline E3 & & & X & O & O & X & A \\
\hline E4 & & & & & X & X & O & A \\
\hline E5 & & & & & X & V & A \\
\hline E6 & & & & & & & V & A \\
\hline E7 & & & & & & & & A \\
\hline E8 & & & & & & & & \\
\hline
\end{tabular}

Source: Data processed from questionnaires

Note: Entries in the table: V when rows affect columns; A when the column affects the line; $\mathrm{X}$ when rows and columns influence each other; and $\mathrm{O}$ when there is no relationship between rows and columns.

Then, based on the interpretation of Rechability Matrix matrix (RM) end it can be arranged a hierarchy of connectivity between factors collaboration fintech based on sharia cooperatives can be described in table 1 above RM initial enabler industrial development strategy fintech sharia built. Furthermore, by entering the concept of transitivity, the final RM is obtained. Transitivity in contextual relationships is a basic assumption made in ISM. This concept states that if the variable $\mathrm{X}$ is related to $\mathrm{Y}$ and $\mathrm{Y}$ is related to $\mathrm{Z}$, then $\mathrm{X}$ must be related to Z.RM also provides driving power and dependence power for each enabler. Thus, in the last RM table (Table 2), the power of influence for $\mathrm{E} 1$ and E2 (Collaboration and government roles) is the total number of entry values in the row, ie 8 . Meanwhile, the power dependence value for $\mathrm{E} 8$ (the number of entries in the column) is 8 . Similarly, the values of driving powerdan dependence powerdihitung for all remaining enableryang $\mathrm{m}$ emberikan that information as follows :

Table 2. Matrix Rechability Matrix (RM)

\begin{tabular}{|l|l|l|l|l|l|l|l|l|l|r|}
\hline No. & E1 & E2 & E3 & E4 & E5 & E6 & E7 & E8 & $\begin{array}{l}\text { Driving } \\
\text { Power }\end{array}$ & Ranking \\
\hline E1 & 1 & 0 & 1 & 1 & 1 & 1 & 1 & 0 & 6 & 2 \\
\hline E2 & 0 & 1 & 1 & 1 & 1 & 1 & 1 & 0 & 6 & 2 \\
\hline E3 & 0 & 0 & 1 & 1 & 1 & 1 & 1 & 0 & 5 & 3 \\
\hline E4 & 0 & 0 & 1 & 1 & 1 & 1 & 1 & 0 & 5 & 3 \\
\hline E5 & 0 & 0 & 1 & 1 & 1 & 1 & 1 & 0 & 5 & 3 \\
\hline E6 & 0 & 0 & 1 & 1 & 1 & 1 & 1 & 0 & 5 & 3 \\
\hline
\end{tabular}


Elida Elfi Barus

Collaboration In Developing Islamic Micro Finance Institutions (IMFs) Based On Financial Technology

\begin{tabular}{|l|l|l|l|l|l|l|l|l|l|r|} 
E7 & 0 & 0 & 1 & 1 & 1 & 1 & 1 & 0 & 5 & 3 \\
\hline E8 & 1 & 1 & 1 & 1 & 1 & 1 & 1 & 1 & 8 & 1 \\
\hline Dep endence & 2 & 2 & 8 & 8 & 8 & 8 & 8 & 1 & & \\
\hline Hierarchy & 2 & 2 & 1 & 1 & 1 & 1 & 1 & 3 & & \\
\hline
\end{tabular}

Source: Data processed from questionnaires

From the last step, the next step is to build the reachibility set and the antecedent set. The range defined for certain enablers consists of the enabler itself and other enablers that can help achieve it. Likewise, the set of antecedents consists of the enabler itself and other enablers that influence it. This set intersection is inherited for all enablers. Enables where the antecedent set and the reachibility set are the same, form the top level of the hierarchy in the ISM model. Enablerini will not help achieve other enablerini above their level (Jabeen \& Faisal, 2018). The level identified helps in establishing the ISM quadrant and final model through the MICMAC classification (matrix of cross impact multiplications applied to classification )

In his research, popularized the cross impact multiplication matrix or MICMAC to classify the system variables under study. The basis of this classification is driving power and dependence power which are calculated in the final RM. In addition, MICMAC analysis can be used to examine the direct and latent relationship between elements obtained from the ISM technique. So, based on driving power and dependence power, the enablers in this study are classified into four groups, as shown and explained below:

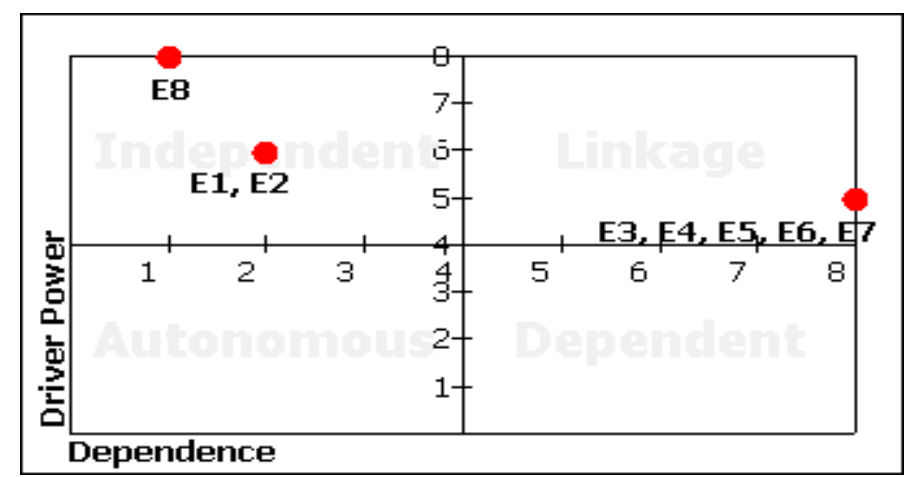

Figure 3 : Driving power and dominance diagram of the enablers

Figure 3 shows the level of problems and challenges in the development of sharia fintech collaboration in the Indonesian sharia cooperative. Important issues include the lack of educational instruments to Department of Cooperatives and SMEs (E8) at level 1 as a key level. Then there is academic (E1) and Financial Fervices Authority (E2) at level 2. 
and the last challenge that is no less important is the collaboration is suppor Sharia Cooperative institutions (E3), Fintech Sharia (E4), Micro small and Medium Enterprises (E5) and AFSI (E6) and AFPI (E7) at level 3.

$\begin{array}{lr}\text { Level 1: } & \text { E3, E4, E5, E6, E7 } \\ \text { Level 2: } & \text { T1, E2 } \\ \text { T } \\ \text { Level 3: } & \text { E8 }\end{array}$

Figure 4. Level is the collaboration of Sharia Cooperative with Fintech Syariah

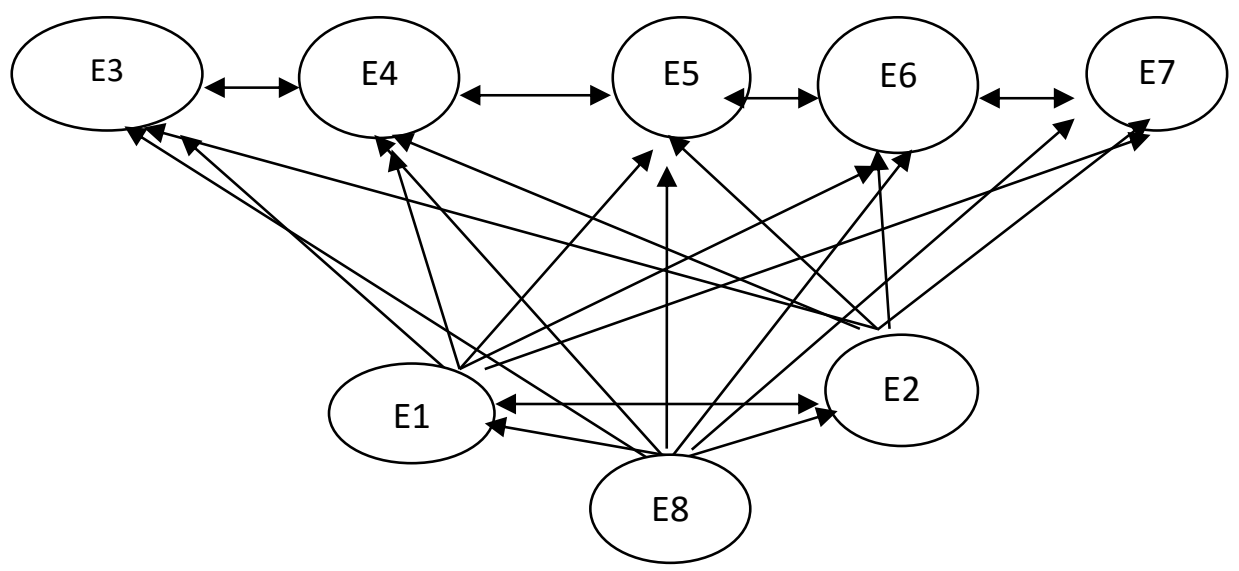

Figure 5. Digraph of factors for coordinated and responsive supply chains showing the relationship between the factors

OJK Regulation Number 77 / POJK.01 / 2016 concerning Direct Technology Based Loan Services, and Bank Indonesia Number 19/12 / PBI / 2017 concerning the implementation of Technology financial, the concept of Islamic fintech is not included in the regulations mentioned. Likewise, the regulation is being compiled by the OJK, where the concept of sharia is not contained in it. OJK explained that the rules drawn up were legal umbrella. That means that the rules govern fintech companies in general. However, there is a possibility that the authorities will issue special regulations (related to Islamic fintech) in the near future. Moreover, the sharia-based financial services market is quite popular in today's society. Regarding HR, which is the second challenge, this is often a common problem faced by other industries though. For example in the world of Islamic banking (Rusydiana, 2016) and microfinance, the problem of $\mathrm{HR}$ is a crucial thing that needs to be sought a solution. The same thing happened to other sharia financial industries (Rusydiana \& Devi, 2017) 


\section{Elida Elfi Barus}

Collaboration In Developing Islamic Micro Finance Institutions (IMFs) Based On Financial Technology

With reference to the results of processing with the ISM method shows that the strategies needed in the framework of the development of sharia cooperatives in collaboration with sharia fintech in Indonesia, the strategy considered important is that these activities are aimed at growing new cooperatives and improving the quality of institutional sharia cooperatives so that sharia cooperatives can grow, develop and run in accordance with the objectives of Islamic cooperatives. The strategic direction is implemented through focus on cooperative SMEs in developing cooperatives of all policies and support, especially to Islamic cooperatives, collaborating with sharia fintech as advice in capital (P2P) for the advancement of cooperatives. then the second focus is OJK as the regulator and academics as the drafter. the last is then supported by the fintech community such as AFSI, AFPI, Ammana and actors such as KSPPS / BMT and Micro Finance Institution.

\section{Conclusion}

From the discussion it can be concluded that there are 8 factors based on the opinions of experts contained in the development of fintech-based sharia cooperatives that the key evaluation is the lack of education and promotion of collaboration of Islamic financial institutions, especially in sharia cooperatives with sharia fintech (E9) which were originally fintech become a competitor to financial institutions because it is very flexible and fast and has been instructed by the OJK that fintech must collaborate with financial institutions including sharia ones. By doing this ISM analysis of this development strategy expected in a pat into an evaluation of the effectiveness of the collaboration cooperative sharia sharia fintech with 6 strategic direction. Furthermore, it can be suggested for legislators, actors and drafter to always monitor and improve the process in the context of the progress and welfare of cooperatives and Micro Finance Institution in Indonesia. 


\section{References}

Adrian Teja, Indonesian Fintech Business: New Innovation or Foster and Collaborate in Business Ecosystem? The Asian Journal of Technology Manage ment Vol 10 No. 12017.

Alaa Alaabed, Finocracy, and Abbas Mirakhor. "Accelerating Risk Sharing Finance via FinTech: NextGen Islamic Finance." The 1st International Colloquium on Islamic banking and Finance. 2017.

Apriyani .. OJK: Beware of the impact of Sharia Cooperative technology. Infobanknews. Accessed 6 October 2016. Available at http://infobanknews.com. 2016

Arner, Douglas W., Janos Barberis, and Ross P. Buckley. " The evolution of Fintech: A new postcrisis paradigm. " Geo. J. Int'l L. 47 , 2015.

Arslanian, Henri and Fischer, Fabrice, The Future of Finance: The Impact of Fintech, AI and Crypto on Financial Services, Palgrave Macmillan, Switzerland, 2019.

Avelana Saksonova, Irina Kuzmina and Merlino, Fintech as Financial Innovation-The Possibilities and Problems of implementation, European Journal of Studies Studies Vol XX Issue 3A 2017 p, 961-973

Ayuda Prayitna and Henry Nugroho, Information Systems Development Model Based on Technology Accepted Model and Ajax Technology in Savings and Credit Cooperatives. This article was presented at the Innovative and Creative Information Technology Conference (ICITech) with the theme "E-Transaction and Power Play" organized by the Informatics Engineering Study Program, Faculty of Information Technology, Satya Wacana Christian University, Salatiga, 24 November 2016.

Baihaqi, Jadzil." Sharia-based Financial Technology Peer-To-Peer Lending in Indonesia ." TAWAZUN: Journal of Sharia Economic Law 1.2 (2018): 116-132.

Barus, Elida Elfi, and Muhammad Syahbudi. " Strategic Development of Islamic Technology-Based Sharia Cooperatives with Structural Modeling Interpretive Approaches." National Seminar on Information Science and Technology (SENSATION). Vol. 2. No. 1. 2019.

Bensar, Fatima Z., and Gonzalo Rodríguez. "Islamic Fintech and the paradigm shift in the financial landscape." Islamic Social Finance. Routledge, 2018. 145-159.

Bhandari, Vibha. "FinTech: A Study of Enablers, Opportunities, and Challenges in the Banking and Financial Services Sector." Financial Technology and Disruptive Innovation in ASEAN. IGI Global, 2020. 108-118.

Biancone, Paolo Pietro, Silvana Secinaro, and Mohamad Kamal. " Crowdfunding and Fintech: sharia compliant business models. " European Journal of Islamic Finance 12 (2019). 


\section{Elida Elfi Barus}

Collaboration In Developing Islamic Micro Finance Institutions (IMFs) Based On Financial Technology

Blakstad, Sofie and Robert Allen, Fintech Revolution: Universal Inclusion of The New Financial Ecosystem, Plagrave Macmillan, Switzerland, 2018

Bulatova, Elvira Ildarovna, et al. "The fintech and Islamic finance synthesis in the modern world ." 3C TIC (2019): 258-273.

Desi et al, SMS Gateway Reminder Payment Reminder Information System at PKK Sejabtera Cooperative BSI Abdimas Journal Vol 1 No 1 Ed February 2018

Faisal, et al, Sharia Principle Operational Prospects in Cooperative Business Activities; Analysis of Efforts to Convert Bandar Lampung Diamond Intellectuals into Cooperatives Based on Sharia Principles, Research Report, Bandar Lampung: IAIN Raden Intan, 2003.

Fatimah, Siti Irma, "Analysis of Islamic Boarding School Cooperative Strategies in People's Economy Empowerment; Study on Al-Iklash Subang Kopontren "Undergraduate Thesis of the Sharia and Law Faculty, Syarif Hidayatullah State Islamic University Jakarta, 2005.

FinTech Weekly: "A business that aims at providing financial services by making use of software and modern technology." bttps:// www.fintechweekly.com/ fintech-definition

Firdaus, Walidur and Bunga Internet Financial Reporting: Financial Tecbnology Feasibility Escalation Description Based On Steakholder As Financial Technology Implementation, Delivered on Proceedings of the 4th National and Call Papers FE Umuhammadiyah Jember, 2018 h. 104-125.

Firmansyah and Widiati .. Maximizing the value of Islamic Sharia Cooperatives through the latest customer service technology. Journal of Finance and Islamic Cooperatives 20 (2): 274281. 2016

Firmansyah, Egi Arvian, and Mokhamad Anwar. "Islamic financial technology (FINTECH): its challenges and prospects." Achieving and Sustaining SDGs 2018 Conference: Harnessing the Power of Frontier Technology to Achieve the Sustainable Development Goals (ASSDG 2018). Atlantis Press, 2019.

Firmansyah, Hafiz Budi, and Ahmad Luky Ramdani. " The role of Islamic financial technology (FinTech) is a start-up in improving financial inclusion in Indonesia case: Angsur. "3rd International Conference of Integrated Intellectual Community (ICONIC). 2018.

Fintech Group, Fintech Syariah Business Study: Study of Expert Management \& User Research Management Program TW II 2017, PT.Telecommunications Indoneis a, Tbk. Downloaded July 2018.

Hamzah, Amir, and Dadang Suhardi. "Level of Financial Literacy and Financial Technology in Micro, Small and Medium Enterprises (Umkm), Kuningan District." JIMFE (Management Scientific Journal of the Faculty of Economics) 5.2 (2020): 97-108. 
Hanun, Amalina Khairina." The Determinants Of Potential Failure Of Islamic Peer-To-Peers 'Lending' ( The Perceptions of Stakeholders in Indonesia)." dspace.uii.ac.id (2019).

Hasan, SBM "Islamic Fintech-A Threat for Islamic Banks or an Opportunity. " Retrieved January 25 (2017): 2018.

Hasan, Rashedul, Mohammad Kabir Hassan, and Sirajo Aliyu. " Fintech and Islamic Finance: Literature Review and Research Agenda. " International Journal of Islamic Economics and Finance (IJIEF) 3.1 (2020): 75-94.

Haqqi, Abdurrahman Raden Aji. "Strengthening Islamic Finance in South-East Asia Through Innovation of Islamic FinTech in Brunei Darussalam. " Economics, Business, and Islamic Finance in the ASEAN Economics Community. IGI Global, 2020. 202-226.

Hudaefi, Fahmi Ali. "How does Islamic fintech promote the SDGs? Qualitative evidence from Indonesia ." Qualitative Research in Financial Markets (2020).

Hui, Ho Wen, Azwina Wati Abdull Manaf, and Asfarina Kartika Mohd Shakri. " Development of Islamic FinTech: Transforming the Islamic Banking and Finance Regulatory Framework in Malaysia." Emerging Issues in Islamic Finance Law and Practice in Malaysia, Emerald Publishing Limited (2019): 211-222.

Imanuel, Adhitiya Wulanta Chrismastianto, SWOT Analysis of the Implementation of Financial Technology on the Quality of Banking Services in Indonesia, Journal of Economics and Business Vol 20 No 1 April 2017

Ilham, Muhammad. Implementation of Strategic Financial Inclusion in the Era of the Digital Economy Against Financial Literacy in Indonesia . Diss repository.umsu.ac.id 2019.

Junaedi B. SM., Islam and Intreprenedrialism: A Fiqh Study of Modern Business Economics, West Java: Kalam Mulia, 1993.

Kaili, Eva, Psycharist and Honaru, Raz van, New Models of Financing and Financial Reporting for Europeas SMEs, Palgrave Macmillan, Switzerland, 2019.

Kurnia., Supriyadi, and Masjono. The effect of the relationship between the utilization of the core banking system application on the individual performance of PT. BRI Syariah Bank. Journal of Accounting, Finance and Islamic Cooperatives (Account) 1 (3): 247-254. 2015.

Kusumaningsih, Ani, et al. " Fintech-Based Entrepreneurship (Financial Technology) Development for Umkm in Cipta Boga Keranggan Cooperative, South Tangerang." Proceedings of Sembadha 1.1 (2018): 192-201.

Lee, In, and Yong Jae Shin." Fintech: Ecosystems, business models, investment decisions, and challenges. " Business Horizons 61.1 (2018): 35-46.

Margaretha, F. The impact of electronic banking on the performance of Indonesian Syariah Cooperatives. Journal of Finance and Islamic Cooperatives 19 (3): 514-524. 2015 


\section{Elida Elfi Barus}

Collaboration In Developing Islamic Micro Finance Institutions (IMFs) Based On Financial Technology

Mills, Karen G, Fintech, Smal Business \& The American Dream (How Technology is Transforming Lending and Shaping a New Era of Small Business Opportunity), Palgrave Macmillan, Switerzerland, 2018.

Muzdalifa, Irma, Inayah Aulia Rahma, and Bella Gita Novalia. " Fintech's Role in Increasing Inclusive Finance at Micro Finance Institution in Indonesia (Sharia Financial Approach)." Journal of Masharif al-Syariah: Journal of Sharia Economics and Banking 3.1 (2018).

Nazwirman Role of Information Technology Based Microfinance Institutions in Developing Micro Enterprises, Journal of The Winners Vol 9 No. 2 September 2008.

Nursiana, A. ... The influence of internet banking, service quality, product reputation, location, on customer loyalty by intermediating customer satisfaction. Journal of Finance and Islamic Cooperatives 19 (3): 450-462. 2015

Nugroho, Feri Adi and Sudibiyo, Usman WEB-based SMS Gateway Information Service Application for Primkopabri Tegal Savings and Credit Cooperatives, Dian Nuswantoro University Computer Science Journal 2016.

Omoola, Sodiq. " Fintech in Islamic Finance-Theory and Practice by Umar A. Oseni and S. Narim Ali (Eds.). " IIUM Law Journal ed. January. : 259-264. 2019

Financial Services Authority. Syariah Cooperatives: Series of college financial literacy . Jakarta: OJK Publisher, 2016

Bank Indonesia Regulation No: 19/12 / PBI / 2017 concerning the implementation of Financial Technology

Peter Gomber, Robert J Kauffman and Bruce W Weber, Financial is Underlying Technologies and The Fintech Revolution, a Call for Papers of the Journal of Management Information Systems, May 2015

Pramana, Atmaja and Sutaman, Role of the Financial Services Authority in Supervising Non-Bank Financial Institutions Based on Fianacial Technology Types of Peer to Peer Lending, FH Journal of Udayana University. 2017

Prawirasasra, Kannya Purnamahatty, Financial Technology in Indonesia: Dissolved or Collaborate? Journal of Economics and Finance Vol 4 No. 22018.

Rahadi., And Zanial .. Analysis of technology acceptance models in the Syariah Cooperative industry . Journal of Information Systems (JSI ) 7 (2): 2015 . .

Rumondang, Astri. " The Utilization of Fintech (P2P Landing) as SME's Capital Solution in Indonesia: Perspective in Islamic Economics (Qirad). " International Conference of Moslem Society. Vol. 2. 2018. 
Rusydiana, Aam Slamet." Developing Islamic financial technology in Indonesia. " Hasanuddin Economics and Business Review 2.2, 2018 .

Rusydiana, Aam Slamet. " How to Develop Sharia Fintech Industry in Indonesia? Interpretive Structural Model (ISM) Approach." A 1-Muzara'ah 6.2, 2018.

Sa'ad, Auwal Adam, and Anwar Bin Allah Pitchay. " Financing SMEs Through the Islamic Qard al-Hasan: A Proposal of Islamic FinTech Interest-Free Lending for Government Initiatives. " Impact of Financial Technology (FinTech) on Islamic Finance and Financial Stability. IGI Global, 2020 .

S aad, Muhammad Aizat, and Wan Nazjmi bin Mohamed Fisol. " Financial Technology (Fintech) Services In Islamic Financial Institutions."

Sa 'ad, Auwal Adam, Khaliq Ahmad, and Abdulmajid Obaid Hasan Saleh. " P2P Islamic Investment Fintech Innovation. A proposal Of Musha rakah Smart Contract Model For SMEs Financing And Social Development." Al-Shajarah: Journal of the International Institute of Islamic Thought and Civilization (ISTAC) , 2019.

Sabree, Ahmad A., and Umar Munshi." The Emergence Of Islamic Crowdfunding Platforms ." Fintech in Islamic Finance: Theory and Practice, 2019.

Setyaningsih, Eka Dyah. "SWOT Analysis of the Implementation of Islamic Financial Technology at PT Telkom Indonesia ." Syiar Iqtishadi: Journal of Islamic Econ omics, Finance and Banking 2.2, $2018 \ldots$

Sudiarianto Application of Support System for Decision on Feasibility of Credit Loans for AndroidBased Cooperative Customers. Ferris Wheel Journal of Information Vol 1 No 1 September 2013.

Sara Feenan and Thlerry Rayna, Blockechain in a Digital World, The Capco Instituue Journal of Financial Transformation ed.44 November 2016

Suwandi, M., AYM Bayan, and ALK Taufiq." Financial Technology Optimization in the Development of Micro Finance Institution with Spotlight Phenomenology. " 17th International Symposium on Management (INSYMA 2020). Atlantis Press, 2020.

Tedjasuksmana, Budianto, and P. Julius F. Nagel. " Cooperative Bank and Financial Technology: Institution and Innovation for Empowerment of Financial Operations Umkm Enter 2025 Post ACFTA (ASEAN China Free Trade Area). Proceedings of the National Seminar on Applied Science and Technology. Vol. 1. No. 1. 2019.

Tobing, Fathorazzi, and Wulandari .. Sharia Cooperative marketing system innovation model based on floating market for the creation of competitiveness (model of Islamic banking marketing innovation systems based on floating market for creation competitiveness). Journal of Finance and Islamic Cooperatives $20(1), 2016$.

Wijaya, Reynold (Coordinator of the P2P Lending Task Force of the FinTech Indonesia Association and CEO \& Co-Founder of Modalku), "Myth of Bank vs FinTech: 


\section{Elida Elfi Barus}

Collaboration In Developing Islamic Micro Finance Institutions (IMFs) Based On Financial Technology

Collaboration, Not Competition, for Indonesian Financial Inclusion" , Accessed May 19, 2018

Winarto, Wahid Wachyu Adi." The role of Fintech in Micro, Small and Medium Enterprises (Micro Finance Institution). " Jesya (Journal of Economic \& Sharia Economics) 3.1 , 2020 .

Wulan, Veqi Rahman, Financial Technology (Fintech) A New Transaction in Future, Journal of Electrical Engineering and Computer Science Vol 2 No 1 June 2017,

Yanti, Tri Auri, Saparuddin Siregar, and Sugianto Sugianto. " Analysis of BPRS Strategy in North Sumatra in Facing Competition in the Fintech Era." Proceeding International Seminar of Islamic Studies. Vol. 1. No. 1. 2020.

Yasini, Sirajulhaq, and Marifatulhaq Yasini. " Current trends and future impacts of fintech in Islamic finance." Fintech in Islam c Finance: Theory and Practice 2019

Yuliana, Rr Retno Rizki Early. "Synergy of Financial Technology Institutions and Cooperatives in Utilizing Financial Technology by Micro, Small and Medium Enterprises in NTB ." Journal of Economics and Development 27.12019.

Yoshida, Etsuaki. " Fintech-Enabled Islamic Financial System and Financial Stability." Islamic Monetary Economics and Institutions. Springer, Cham, 2019 ..

Zainil Ghulam, Implementation of Maqasid Syariah in Sharia Cooperatives, Iqtishoduna Journal Vol 7 No. 1 April 2016

Zaid Zamanda, Business Feasibility Analysis Starup Financial Technology (Case Study: Starup Sharvest) Final project of Faculty of Engineering . Engineering Andalas University, Padang 2018

Zerra, Mecky. " Pelix-Tech in Collaboration: The Implementation of the Penta Helix Model in Financial Technology To Promote Increased Financial Inclusion and Financial Literacy in Indonesia ." academia.edu 